\title{
Learner Perceptions and Teacher Beliefs about Learner Autonomy in Language Learning
}

Khem Raj Joshi

\begin{abstract}
Learner autonomy is one of the intriguing phenomena in the field of SLA. This has become the focal point for many scholars and researchers these days. The present study was carried out to make a survey of autonomous learning activities of the Master level students, majoring in English Education, Tribhuvan University, Nepal. It also explored their perceptions on the roles of their own and their teachers' roles, and how it has been looked at from the teachers' viewpoint. Adopting a mixed methodological design and analyzing the data collected through questionnaire and semi-structured interview, it was found that the learners make a good practice of autonomous activities. They view their role as an important factor in learning. The teachers have also suggested the learners to be autonomous. The teachers as well as the learners were found highly positive towards autonomous learning.
\end{abstract}

Key words:Autonomy, Contexts, Learner, Independent learning, Technology

\section{Introduction}

$\mathrm{T}$ he term autonomy refers to one's ability to decide the laws for oneself. The concept is found in moral, political and bio-ethical philosophy. It has been defined in a number of ways. Holec (1983, as cited in Benson and Voller, 1997, p.1) defines it as "the ability to take charge of one's learning" by determining the objectives; defining the contents and progressions; selecting methods and techniques to be used; monitoring the procedure of acquisition by properly speaking; and evaluating what has been acquired. Little (1991) stands at the same pole and defines LA as a capacity- for detachment, critical reflection, decision-making, and independent action (p.4). He further explains that it presupposes, but also entails that the learner will develop a particular kind of psychological relation to the process and content of his learning. The capacity for autonomy will be displayed both in the way the learner learns and in the way he or she transfers what has been learned to wider contexts.

Both the definitions mentioned above focus on LA as having the characteristics of being free from external constraints, i.e. as a 'capacity'. Dickinson (1987) also goes to the same direction, and views autonomy as "a mode of learning; one in which the individual is responsible for all the decisions connected with her learning, and undertakes the implementation of these decisions" (p.27). For him, it is the complete responsibility for one's learning carried out without the investment of a teacher or pedagogic materials. However, learners may also differ in terms of their degrees in taking such responsibility, i.e. their ways and extents of being involved in such activities may differ. Dickinson's definition above represents high degree of autonomy, the one where the learner chooses what, how and when of learning without the constraints of formal education. Crabbe (1993, p.443) presents the matching argument to the definitions above that "the individual has the right to be free to exercise his or her own choices as in other areas, and not become a victim (even an unwitting one) of choices made by social institutions". These two definitions take autonomy as a situation where the learner is totally free for all 
the decisions concerned with learning. For Trim (1976), "autonomy is an adaptive ability allowing learners to develop supportive structures within themselves rather than to have them erected around them" (as cited in Esch, 1996, p.37). Candy (1988) concludes autonomy as an innate capacity of the individuals which may be suppressed or distorted by institutional education. Thus, he defines it in the context of formal education drawing upon the risk that formal education can impact into the learners' freedom in making their own choices. Young (1986, p.19) follows the similar path stating that "the fundamental idea in autonomy is that of authoring one's own world without being subject to the others". Pennycook (1997) also takes LA in the similar way defining it as "the struggle to become the author of one's own world, to be able to create own meaning, to pursue cultural alternatives amid the cultural politics of everyday life" (p.39).

Likewise, Frieire (1996) takes autonomy as the learners' capacity and freedom to construct and reconstruct the taught knowledge. That is, it is the ability to create the learning situations and recreate what they have already got of the situations and the knowledge. Although the concept of freedom is still an important issue, Friere (ibid) does not regard the importance of the teachers, whose role in his view, is not to transmit knowledge, but to create possibilities for the students' own production or construction of knowledge.

Thus, we can define an autonomous person as one who has capacity to make and carry out the choices which govern his or her actions independently. This capacity depends on two main factors, ability and willingness. A person may have the ability to make independent choices but he/she may not have willingness to do so because such behaviour is not perceived as appropriate to his or her role in a particular situation. On the other hand, a person may be willing to exercise independent choices but not have ability to do so.

The definition by Boud (1988) illustrates autonomy as an approach to learning. According to him (ibid, p. 23), "the main characteristic of autonomy as an approach to learning is that students take some significant responsibility for their own learning over and above responding to instruction". To state in other words, LA is the ability to assume responsibility for one's own affairs - the ability to act in situation in which he (the learner) is totally responsible for all the decisions concerned with his learning and the implementation of the decisions.

Allwright (1990) views autonomy as a constantly changing but at any time optimal state of equilibrium between maximal self-development and human interdependence (p.12, as cited in). For him, LA is the phenomenon that goes on changing, where the change is towards self-development and less dependence. Cotterall (1995), on the other hand, defines it as "the extent to which learners demonstrate the ability to use a set of tactics for taking control of their learning" (p.195). She describes it as the behaviours that the learners use to establish independence. Kenny (1993, p.436) gives a broader definition and sees it as the "opportunity to become a person", not only the freedom to learn. It refers to all the decisions and activities of independent learning. According to Hedge (2000, p. 410), it is "the ability of the learner to take responsibility for his or her own learning and to plan, organize, and monitor the learning process independently of the teacher". She correlates the concept mainly to the area of formal instruction in this sense. Observing all the definitions above, we can have a common point: they refer to a concept that the learners are involved in their own learning process. Autonomous learning, thus, reaches beyond a social context.

As Benson and Voller (1997) emphasize, the term LA comes to be used at least in the following five ways: situations in which learners entirely study on their own; a set of skills which can be learned and applied in the self-directed learning; an inborn capacity which is suppressed by institutional education; the exercise of learners' responsibility for their own learning; and the right of learners to determine the direction of their own learning.

Thus, the term LA has been used very broadly. However, it is used to refer to the capacity of a person to work out without being controlled by other people. The concept may refer to the situations where one learns without being dragged by the others and the actions done on self for learning. It is taken as the ability to act and make decisions without being controlled by anyone else. In a nutshell, the term refers to learners' ability of taking one's own responsibility. 


\section{Learner autonomy: the misconceptions}

Learner autonomy is found to be quite a complex notion not only from the semantic view point, but also for several other reasons. It encompasses concepts from different disciplines of study (e.g. philosophy, language, politics etc.). Benson (1997) makes announced distinction between 'selfdirected learning' and 'learner autonomy'. For him, 'self-directed learning' is learners' global capacity to carry out learning; while 'autonomous learning' is the particular personal characteristic associated with such a capacity. But the term learner autonomy has been viewed as synonymous with individualization. According to him, there are a number of terms related to autonomy, which can be distinguished from it in various ways. Most people now agree that autonomy and autonomous learning are not synonyms of selfinstruction, self-access; self-study, self-education, out-of-class learning or distance learning (Benson, 2001). These terms describe various ways and degrees of learning by oneself; whereas autonomy refers to abilities or attitudes. The point is then that, learning by oneself is not the same thing as having the capacity to learn-by oneself. Thus, the complexity exists at the semantic level.

Therefore, it can be concluded that autonomy is a complex socio-cognitive system, subject to internal and external constrains which manifests itself in different degrees of independence and control of one's own learning process. It involves capacities, abilities, attitudes, willingness, decision-making, choices, planning, actions and assessment either as a language learner or as a communication inside or outside the classroom. As a complex system, it is dynamic, chaotic, unpredictable, non-linear, adaptive, open, selforganizing, and sensitive to initial conditions and feedback. Because of this complexity, there have been several misconceptions about the definitions of autonomous language learning. To make it clear, Esch (1996, p.37) explains what autonomy does not mean:

- Autonomy is not self-instruction learning without a teacher;

- It does not mean that intervention or initiative on the part of a teacher is banned;

- It is not something teachers do to learners;
- It is not a single easily identifiable behaviour;

- It is not a steady state achieved by learners once and for all.

The other reason why it is misinterpreted is the multi-faceted nature of concept. It consists of a number of elements. The study of LA includes wide range of areas. Few of them are discussed under the context for its application in the following sections. In literature, there are a number of synonymous terms for it. For some writers, the terms:- learner autonomy, autonomous learning, learner responsibility, self-directed learning, lifelong learning and learning to learn are synonymous. Approaches which assist learners to learn are described in various terms, the most common ones are: self-directed learning, selfinstruction, independent learning and self-access learning. Although proponents of these approaches may argue for differences between them, there are more similarities than differences. Each of the approaches encourages learners to set and pursue their personal language learning goals. Though all these approaches are used as the same sometimes, they need to be distinguished from each other too. They can be taken as the different means to LA. The interpretation by Esch above here seems to be much relevant.

\section{Contexts for the application of autonomy}

Learner autonomy is such a broad area that it not only encompasses the classroom situations but also the out-of-class situations. Regarding the contexts in which it is applied. Benson (2007) mentions the two broad topics.

\section{Autonomy beyond the classroom}

Autonomous learners can practice it in a number of ways. To enhance their learning, they can use the various ways and modes. Benson (2007, p.26) encapsulates the followings modes of autonomy beyond the classroom:

Self-Access: To foster autonomy, various selfaccess centers have been established around the world. These centers provide necessary materials where the learners work on their own to learn. Self-access is an approach to learning not an approach to teaching. 
Computer Assisted Language Learning (CALL): Computers and the internet technology have played vital role in learning. CALL as the product of these instruments has facilitated autonomous learning. It is a program where the learners can learn independently using computers.

Distance Learning: Distance learning, the independent learning mode without formal constraints, also reflects the characteristics of autonomous learning.

Tandem Learning: Tandem learning, in which two people are learning each others' language work to help one another, has long association with autonomy (Benson, 2007).

Study Abroad: In study abroad program, students spend time in target language communities. Although many of the programs involve classroom instruction, their main purpose is usually for the students to learn independently through interaction with the native speakers.

Out-of-Class Learning: Several studies have shown that students tend to engage in out-of-class learning activities more frequently than their teachers know.

Self-Instruction: It refers to the use of printed or broadcast self-study materials independent of the teachers and thus, becoming itself a factor of autonomy beyond classroom.

This should be taken into account that these are not only the ways by means of which one becomes autonomous. There can be several such modes of practice, for example, self-study, library study, group learning and so on.

\section{Autonomy in the classroom}

Learners not only are found autonomous beyond classroom but also inside the class. In the broad definition of autonomy, it includes all the decisions made by learners for their own learning. So, all the activities, plans and actions that the learner chooses of him/herself, help to promote it. Inside a class, it might involve different levels of control such as: management for learning, cognitive processes and learning content. It can be reflected in group works, co-operative learning, innovative learning or other classroom actions and activities. So, a learner might seek different ways to be autonomous in a class. They may search the opportunities to learn more things easily, i.e. learn the ways of learning. To sum up, it can be said that classroom is also the context where learner autonomy is practiced at least for learning to learn.

\section{Fostering autonomy The teacher's role}

In autonomous learning, the exact nature of teachers' role like learners', varies according to contexts and personalities involved. Generally, a teacher in such learning is a facilitator, an organizer, a resource person providing learners with feedback and encouragement, and a creator of learning atmosphere and space. In other words, a teacher works as a guide, a co-operative and an initiator rather than an authority.

For Camilleri (1999), the most important role includes 'awareness' of self. Furthermore, the teacher of' autonomous leaner(s) has these characteristics: is aware of her own personal influence on the learning process; understands pedagogy; is skilled in management (p.36). Camilleri (ibid) states the following three roles of such teacher: i) The teacher as a manager-The teacher as a manager is able to map out the most likely paths available to the students and also the consequences of following any particular path. $\mathrm{He} / \mathrm{She}$ is the manager of activities not the source of facts. ii) The teacher as a resource person- As a resource person, the teacher optimizes learning conditions by helping learners be aware of a whole range of alternatives and strategies and by for example, helping them develop an awareness of learning styles (p.37). iii) The teacher as a counselor-The teacher as a counselor is able to accompany individual learning process and to respond meaningfully to learning problems often in advance of a student perceiving a need (p.38). He has to diagnose symptoms of learning distress.

Little et al. (2007) suggest three things in the regard of teacher's role in autonomous learning. The teachers who want to promote the development of learner autonomy must do three things: first, they must involve their learners in their own learning, giving them ownership of learning objectives and the learning process. Secondly, they must get their learners to reflect about learning and about the 
target language. Thirdly, teachers must engage their learners in appropriate target language use, which includes the language of reflection and assessment. These three things that language teachers must do can be summarized as the pedagogical principles of 'learner development', 'learner reflection' and 'appropriate target language use' (ibid.). These all imply that, to develop the responsibility on the part of the learners, teachers have vital roles in the learning process of students.

The closely related concept to the LA is Teacher Autonomy (TA). In many types of learning situation (e.g. classroom learning), the ELT practitioners also raise the issues of TA since many of the teachers yet have been being driven through the traditional principles of teaching. It is the situation whereby a teacher acts as an authority as most of teaching/learning is (e.g. what and how of learning) are controlled by teachers in such cases. LA and TA, in this regard can be taken as mutually exclusive phenomena. This does not mean that teachers should not be autonomous but this should not be misunderstood that freedom of teachers is different from creating their dictatorship.

\section{The learner's role}

It is the learner, who is most responsible for autonomous learning. It necessitates a new role for the learner, a role in which he/she is described as: 'good learner', 'responsible learner' and 'aware learner'. According to Holec (1979), 'a good learner' makes decision regarding: choice of objectives; choice of content and materials; methods and techniques to be used; and how to assess progress and outcomes. 'The responsible learner' is the one, who accepts that his/her own efforts are crucial for effective learning and co-operates with the teachers monitoring own progress through the use of opportunities available. Likewise, 'the aware learner' is the one, who sees the relationship to what is to be learnt, how to learn and the resources available in order to take charge or control of learning. Under such learning, it is the learner who becomes most active. He/she has to do a lot on own with the suggestions and facilitation of teachers. They are freer in the selection of every aspects of learning at the same time they have more responsibilities to be accomplished.

\section{The study}

This study was a survey done among the students and teachers from the Department of English Education, University Campus, Kathmandu, Nepal. The subjects were the graduators and the teachers who regularly attended the University classes. The details of the study are briefly presented here:

\section{Objectives of the study}

The main objectives of this study were to investigate the autonomous activities of the students in learning English:- to explore their beliefs about the role of a teacher and their own in learning and to find out their teachers' perceptions of learner autonomy.

\section{Methodology}

The population of this study consisted of 80 master's level students and 6 teachers from the Department of English Education, University Campus, Tribhuvan University, Kirtipur, Kathmandu. They were selected as the population of the study since the researcher was interested in knowing how they were conducting teaching/ learning activities in such crowded classes and what they were doing beyond. So, the study area and the population were selected purposively. Then, the students were selected randomly through fish-bowl draw; while the teachers were selected purposively.

The tools used in the research were a questionnaire and an interview schedule. The questionnaire was distributed to the students to collect quantitative data. Additionally, a semi-structured interview sheet was used to elicit the data from the teachers so as to get the greater detail of the autonomous learning (see appendix for the tools). The researcher prepared the tools being based on the ideas of the researchers like Zhang and Li (2004), Lamb and Reinders (2008), and others.

\section{Discussion}

The data was collected and analyzed under three main sub-headings: autonomous learning activities and plans; the learners' perceptions of autonomous learning; and the teachers' perceptions of autonomous learning: 


\section{Autonomous learning activities and plans}

The statements which were included in the questionnaire to elicit the subjects' autonomous learning activities and plans are divided into seven subheadings: learner awareness, self-effort, broader autonomous activities, self-esteem, use of reference materials, motivation, and use of technology in learning.

\section{Learner awareness}

Table 1: Learners' Awareness in Language Learning

\begin{tabular}{|c|c|c|c|c|c|c|c|c|c|c|c|c|c|c|c|c|}
\hline \multirow{4}{*}{ No. } & \multirow{4}{*}{ Items } & \multicolumn{14}{|c|}{ Responses } & \multirow{4}{*}{$\sum_{\Sigma}^{\frac{5}{\sigma}}$} \\
\hline & & \multicolumn{6}{|c|}{ Rarely } & $\begin{array}{l}\text { Some- } \\
\text { times }\end{array}$ & & \multicolumn{6}{|c|}{ Always } & \\
\hline & & \multicolumn{2}{|c|}{$\begin{array}{l}\text { Never } \\
\text { (1) }\end{array}$} & \multicolumn{2}{|c|}{ Rarely (2) } & \multicolumn{2}{|c|}{ Total } & & \multicolumn{2}{|c|}{ Often (4) } & \multicolumn{2}{|c|}{ Always (5) } & \multicolumn{2}{|c|}{ Total } & & \\
\hline & & $\mathbf{N}$ & $\%$ & $\mathbf{N}$ & $\%$ & $\mathbf{N}$ & $\%$ & $\mathbf{N}$ & $\%$ & $\mathbf{N}$ & $\%$ & $\mathbf{N}$ & $\%$ & $\mathbf{N}$ & $\%$ & \\
\hline 1. & $\begin{array}{l}\text { I think I have the ability to } \\
\text { learn English well. }\end{array}$ & 3 & 3.75 & 2 & 2.50 & 5 & 6.25 & 4 & 5.00 & 19 & 23.75 & 52 & 65.00 & 71 & 88.75 & 4.44 \\
\hline 2. & $\begin{array}{l}\text { I make decisions and set } \\
\text { goals of my learning. }\end{array}$ & 2 & 2.50 & 7 & 8.75 & 9 & 11.25 & 10 & 12.50 & 25 & 31.25 & 36 & 45.00 & 61 & 76.25 & 4.06 \\
\hline 3. & $\begin{array}{l}\text { I make good use of my free } \\
\text { time in studying English. }\end{array}$ & 1 & 1.25 & 4 & 5.00 & 5 & 6.25 & 33 & 41.25 & 32 & 40.00 & 10 & 12.50 & 42 & 52.50 & 3.58 \\
\hline & id Mean & & & & & & & & & & & & & & & 4.03 \\
\hline
\end{tabular}

Legend: No. = Item Serial Number, $\mathrm{N}=$ Number of Responses, $\%=$ Responses in Percentage

The vast majority of the students, i.e. $88.75 \%$ of them always thought that they had the ability to learn English well. Analyzing the responses to item 2; $76.25 \%$ of the learners made decisions and set their goals in learning frequently. The responses to the item 3 show that $52.50 \%$ of them made good use of their free time in studying English. In order to view their awareness in average, the weighted mean and the grand mean were calculated. The table shows the mean of 4.44 for the item 1, 4.06 for the item 2 and 3.58 for the item 3. The grand mean 4.03 also shows that the learners were highly aware in their learning.

\section{Self-efforts}

Table 2: Learners' Self-efforts in Learning English

\begin{tabular}{|c|c|c|c|c|c|c|c|c|c|c|c|c|c|c|c|c|}
\hline \multirow{4}{*}{ No. } & \multirow{4}{*}{ Items } & \multicolumn{14}{|c|}{ Responses } & \multirow{4}{*}{$\stackrel{\Sigma}{\Sigma}_{\Sigma}^{\Sigma}$} \\
\hline & & \multicolumn{6}{|c|}{ Rarely } & $\begin{array}{l}\text { Some- } \\
\text { times }\end{array}$ & & \multicolumn{6}{|c|}{ Always } & \\
\hline & & \multicolumn{2}{|c|}{$\begin{array}{l}\text { Never } \\
\text { (1) }\end{array}$} & \multicolumn{2}{|c|}{$\begin{array}{l}\text { Rarely } \\
\text { (2) }\end{array}$} & \multicolumn{2}{|r|}{ Total } & \multirow[b]{2}{*}{$\mathrm{N}$} & \multicolumn{2}{|c|}{ Often (4) } & \multicolumn{2}{|c|}{$\begin{array}{c}\text { Always } \\
(5)\end{array}$} & \multicolumn{2}{|c|}{ Total } & & \\
\hline & & $\mathrm{N}$ & $\%$ & $\mathrm{~N}$ & $\%$ & $\mathrm{~N}$ & $\%$ & & $\%$ & $\mathrm{~N}$ & $\%$ & $\mathbf{N}$ & $\%$ & $\mathrm{~N}$ & $\%$ & \\
\hline 4. & $\begin{array}{l}\text { I preview before the class (i.e. see } \\
\text { summary, lessons etc.). }\end{array}$ & 3 & 3.75 & 8 & 10.00 & 11 & 13.75 & 29 & 36.25 & 28 & 35.00 & 12 & 15.00 & 40 & 50.00 & 3.48 \\
\hline 5. & $\begin{array}{l}\text { In the class, I try to use every op- } \\
\text { portunity to take part in the activi- } \\
\text { ties where and when I can speak } \\
\text { in English. }\end{array}$ & 2 & 2.50 & 12 & 15.00 & 14 & 17.50 & 32 & 40.00 & 21 & 26.25 & 13 & 16.25 & 34 & 42.50 & 3.54 \\
\hline 6. & $\begin{array}{l}\text { I speak confidently in front of the } \\
\text { people. }\end{array}$ & 2 & 2.50 & 8 & 10.00 & 10 & 12.50 & 14 & 17.50 & 28 & 35.00 & 28 & 35.00 & 56 & 70.00 & 3.90 \\
\hline 7. & $\begin{array}{l}\text { I make notes and summaries of my } \\
\text { lessons. }\end{array}$ & 1 & 1.25 & 5 & 6.25 & 6 & 7.50 & 17 & 21.25 & 29 & 36.25 & 28 & 35.00 & 57 & 71.25 & 3.98 \\
\hline
\end{tabular}


Those items in the table above were to measure the autonomous activities and plans that the learners used beyond the class activities of M.Ed. program. The table shows that only $31.25 \%$ of the population always practiced English outside the class also through recording their own voices, speaking to other people in English or other such activities. But $36.25 \%$ did not agree to item 9; while $32.50 \%$ did it sometimes. The average value 2.88 shows the activity was practiced only by an average number of the students. Regarding item 10 - the use of library to learn English, 37.50\% always used it as their part of autonomous learning activities. On the contrary, $21.25 \%$ of them used only rarely and $41.25 \%$ used library only sometimes. The mean is 3.26 , which shows that the students made good use of library. We can also observe that item 11 was always practiced by a great number, i.e. 53.75\%. There were only 17.50 $\%$ who rarely used the audio- visual materials to develop speech. The students who sometimes did so remained $28.75 \%$ of the learners. The average value is 3.49 . Item 12 was prepared to assess how often the students attended different seminars, training courses and conferences to improve their English. The results show that only a minority (i.e. 15\%) of them always undertook the activity. The majority or $52.50 \%$ did it rarely; while $32.50 \%$ of them practiced it sometimes. The weighted mean 2.45 reflects the low adoption of the activity. Whether the students took risk in learning English or not was investigated by item 13 . The analysis is that $48.75 \%$ took risk in learning $31.25 \%$ did rarely; and $20 \%$ of the subjects could do so only sometimes. The mean of the responses 3.30 implies that the students also practice the activity on average. The average of all the means is 3.08 .

\section{Self-esteem}

Table 4: Learners' Self-esteem

\begin{tabular}{|c|c|c|c|c|c|c|c|c|c|c|c|c|c|c|c|c|}
\hline \multirow{4}{*}{ No. } & \multirow{4}{*}{ Items } & \multicolumn{14}{|c|}{ Responses } & \multirow{4}{*}{ 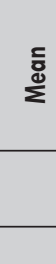 } \\
\hline & & \multicolumn{6}{|c|}{ Rarely } & $\begin{array}{l}\text { Some- } \\
\text { times }\end{array}$ & & \multicolumn{6}{|c|}{ Always } & \\
\hline & & \multicolumn{2}{|c|}{$\begin{array}{l}\text { Never } \\
\text { (1) }\end{array}$} & \multicolumn{2}{|c|}{$\begin{array}{l}\text { Rarely } \\
\text { (2) }\end{array}$} & \multicolumn{2}{|c|}{ Total } & & \multicolumn{2}{|c|}{$\begin{array}{l}\text { Often } \\
(4)\end{array}$} & \multicolumn{2}{|c|}{$\begin{array}{c}\text { Always } \\
(5)\end{array}$} & \multicolumn{2}{|c|}{ Total } & & \\
\hline & & $\mathrm{N}$ & $\%$ & $\mathrm{~N}$ & $\%$ & $\mathrm{~N}$ & $\%$ & $\mathbf{N}$ & $\%$ & $\mathrm{~N}$ & $\%$ & $\mathbf{N}$ & $\%$ & $\mathbf{N}$ & $\%$ & \\
\hline 14. & $\begin{array}{l}\text { I note my strengths } \\
\text { and weaknesses in } \\
\text { learning English and } \\
\text { improve them. }\end{array}$ & 8 & 10.00 & 13 & 16.25 & 21 & 26.25 & 22 & 27.50 & 19 & 23.75 & 18 & 22.50 & 37 & 46.25 & 3.33 \\
\hline \multicolumn{2}{|c|}{ Grand Mean } & & & & & & & & & & & & & & & 3.33 \\
\hline
\end{tabular}

This item was designed to find out whether the students evaluated themselves or not. Based on the responses, $46.25 \%$ of them were found positive. 'Rarely' has been responded by $26.25 \%$ of the subjects; while $27.50 \%$ agreed 'sometimes'. The mean value 3.33 calculated for the item shows that students evaluated themselves through noting their strengths and weakness in learning, and improved them.

\section{Use of reference materials}

Table 5: Learners' use of references materials

\begin{tabular}{|c|c|c|c|c|c|c|c|c|c|c|c|c|c|c|c|c|}
\hline \multirow{4}{*}{ No. } & \multirow{4}{*}{ Items } & \multicolumn{14}{|c|}{ Responses } & \multirow[t]{4}{*}{ s } \\
\hline & & \multicolumn{6}{|c|}{ Rarely } & $\begin{array}{l}\text { Some- } \\
\text { times }\end{array}$ & & \multicolumn{6}{|c|}{ Always } & \\
\hline & & \multicolumn{2}{|c|}{$\begin{array}{l}\text { Never } \\
\text { (1) }\end{array}$} & \multicolumn{2}{|c|}{$\begin{array}{l}\text { Rarely } \\
\text { (2) }\end{array}$} & \multicolumn{2}{|c|}{ Total } & & \multicolumn{2}{|c|}{ Often (4) } & \multicolumn{2}{|c|}{$\begin{array}{c}\text { Always } \\
\text { (5) }\end{array}$} & \multicolumn{2}{|c|}{ Total } & & \\
\hline & & $\mathrm{N}$ & $\%$ & $\mathrm{~N}$ & $\%$ & $\mathrm{~N}$ & $\%$ & $\mathrm{~N}$ & $\%$ & $\mathbf{N}$ & $\%$ & $\mathbf{N}$ & $\%$ & $\mathrm{~N}$ & $\%$ & \\
\hline 15. & $\begin{array}{l}\text { Irevise lessons and seek the } \\
\text { reference books. }\end{array}$ & 1 & 1.25 & 15 & 18.75 & 16 & 20.00 & 20 & 25.00 & 31 & 38.75 & 13 & 16.25 & 44 & 55.00 & 3.50 \\
\hline
\end{tabular}




\begin{tabular}{|l|l|l|l|l|l|l|l|l|l|l|l|l|l|l|l|l|}
\hline 16. & $\begin{array}{l}\text { Besides the contents pre- } \\
\text { scribed in the course, I read } \\
\text { extra materials in advance. }\end{array}$ & 4 & 5.00 & 9 & 11.25 & 13 & 16.25 & 29 & 36.25 & 26 & 32.50 & 12 & 15.00 & 38 & 47.50 & 3.41 \\
\hline
\end{tabular}

Table 5 shows more than half ( $55 \%)$ of them revised the lessons and sought reference materials. On the other side, $20 \%$ of them rarely tried with such activities and $25 \%$ did sometimes. The average value of the responses in item 15 sustained 3.50 depicting that most students were positive to the practice of this activity. Observing the responses to item 16; $47.5 \%$ agreed to 'always' that they always read extra materials besides those prescribed in their course. But $16.25 \%$ responded to 'rarely'; while $36.25 \%$ decided 'sometimes'. The mean is 3.41 . The grand mean 3.46 shows that generally the students using reference are higher than those who do not use.

\section{Motivation}

Table 6: Learners' Self-Motivation in Leaning

\begin{tabular}{|c|c|c|c|c|c|c|c|c|c|c|c|c|c|c|c|c|}
\hline \multirow{4}{*}{ No. } & \multirow{4}{*}{ Items } & \multicolumn{14}{|c|}{ Responses } & \multirow{4}{*}{$\stackrel{\bar{g}}{\Sigma}$} \\
\hline & & \multicolumn{6}{|c|}{ Rarely } & $\begin{array}{l}\text { Some- } \\
\text { times }\end{array}$ & & \multicolumn{6}{|c|}{ Always } & \\
\hline & & \multicolumn{2}{|c|}{$\begin{array}{l}\text { Never } \\
\text { (1) }\end{array}$} & \multicolumn{2}{|c|}{$\begin{array}{l}\text { Rarely } \\
\text { (2) }\end{array}$} & \multicolumn{2}{|c|}{ Total } & & \multicolumn{2}{|c|}{ Often (4) } & \multicolumn{2}{|c|}{$\begin{array}{c}\text { Always } \\
\text { (5) }\end{array}$} & \multicolumn{2}{|c|}{ Total } & \multirow[b]{2}{*}{$\%$} & \\
\hline & & $\mathrm{N}$ & $\%$ & $N$ & $\%$ & $\mathbf{N}$ & $\%$ & $\mathrm{~N}$ & $\%$ & $\mathbf{N}$ & $\%$ & $N$ & $\%$ & $\mathbf{N}$ & & \\
\hline 17. & $\begin{array}{l}\text { When I make progress in } \\
\text { learning, I reward myself such } \\
\text { as: buy new things, celebrate } \\
\text { parties etc. }\end{array}$ & 20 & 25.00 & 20 & 25.00 & 40 & 50.00 & 24 & 30.00 & 5 & 6.25 & 11 & $\begin{array}{c}1 \\
3.75\end{array}$ & 16 & 20.00 & 2.59 \\
\hline \multicolumn{16}{|c|}{ Grand Mean } & 259 \\
\hline
\end{tabular}

Item 17 as in the table 6 was used to find out the students' self-motivation. Half of the students disagreed the item saying that they rarely did such activities. Only $30 \%$ tended to reward themselves when they made progress by buying new things or celebrating parties or else. On the other hand, $20 \%$ agreed to the statement. The weighted mean 2.59 shows that only few of the students made practice of this activity.

\section{Use of technology in learning}

Table 7: Learners' use of computers and internet for learning English

\begin{tabular}{|c|c|c|c|c|c|c|c|c|c|c|c|c|c|c|c|c|}
\hline \multirow{4}{*}{ No. } & \multirow{4}{*}{ Items } & \multicolumn{14}{|c|}{ Responses } & \multirow{4}{*}{$\stackrel{\bar{\sigma}}{\Sigma}$} \\
\hline & & \multicolumn{6}{|c|}{ Rarely } & $\begin{array}{l}\text { Some- } \\
\text { times }\end{array}$ & & \multicolumn{6}{|c|}{ Always } & \\
\hline & & \multicolumn{2}{|c|}{$\begin{array}{l}\text { Never } \\
\text { (1) }\end{array}$} & \multicolumn{2}{|c|}{$\begin{array}{l}\text { Rarely } \\
\text { (2) }\end{array}$} & \multicolumn{2}{|c|}{ Total } & \multirow[b]{2}{*}{$\mathbf{N}$} & \multicolumn{2}{|c|}{ Often (4) } & \multicolumn{2}{|c|}{ Always (5) } & \multicolumn{2}{|c|}{ Total } & & \\
\hline & & $\mathbf{N}$ & $\%$ & $\mathbf{N}$ & $\%$ & $\mathbf{N}$ & $\%$ & & $\%$ & $\mathbf{N}$ & $\%$ & $\mathbf{N}$ & $\%$ & $\mathbf{N}$ & $\%$ & \\
\hline 18. & $\begin{array}{l}\text { I use internet and } \\
\text { computers to study } \\
\text { and improve English. }\end{array}$ & 9 & 11.25 & 21 & 26.25 & 30 & 37.50 & 26 & 32.50 & 17 & 21.25 & 7 & 8.75 & 24 & 30.00 & 2.90 \\
\hline \multicolumn{2}{|c|}{ Grand Mean } & & & & & & & & & & & & & & & 2.90 \\
\hline
\end{tabular}

Table 7 shows the learners' responses regarding their use of internet and computers in learning English. 
The results of their responses were that $30 \%$ always used such technologies in learning; $32.50 \%$ did it sometimes but $37.50 \%$ used rarely. On the average, not many students used these technologies in learning English. This average is found to be 2.90 .

\section{The learners' perceptions of the roles in learning}

Learners' perceptions regarding the role of a teacher and their own in learning might be different from one to another. Here is the analysis of how the M.Ed. students, selected in this study, have viewed such roles particularly in the practice of autonomous learning.

\section{The role of learner}

Table 8: Learners' perceptions of their own roles

\begin{tabular}{|c|c|c|c|c|c|c|c|c|c|c|c|c|c|c|c|c|}
\hline \multirow{4}{*}{ No. } & \multirow{4}{*}{ ltems } & \multicolumn{14}{|c|}{ Responses } & \multirow{4}{*}{$\begin{array}{l}\text { c } \\
\text { एँ }\end{array}$} \\
\hline & & \multicolumn{6}{|c|}{ Disagree } & \multirow{2}{*}{$\begin{array}{l}\text { Unde- } \\
\text { cided } \\
\text { UD (3) }\end{array}$} & & \multicolumn{6}{|c|}{ Agree } & \\
\hline & & \multicolumn{2}{|c|}{ SD(1) } & \multicolumn{2}{|c|}{$\mathrm{DA}(2)$} & \multicolumn{2}{|c|}{ Total } & & \multicolumn{2}{|c|}{$A(4)$} & \multicolumn{2}{|c|}{$\mathrm{SA}(5)$} & \multicolumn{2}{|c|}{ Total } & & \\
\hline & & $\mathrm{N}$ & $\%$ & $\mathbf{N}$ & $\%$ & $\mathrm{~N}$ & $\%$ & $\mathrm{~N}$ & $\%$ & $\mathrm{~N}$ & $\%$ & $\mathrm{~N}$ & $\%$ & $N$ & $\%$ & \\
\hline 19. & $\begin{array}{l}\text { Students have to be } \\
\text { responsible for find- } \\
\text { ing their own ways of } \\
\text { practicing English. }\end{array}$ & 2 & 2.50 & 4 & 5.00 & 6 & 7.50 & - & - & 39 & 48.75 & 35 & 43.75 & 74 & 92.50 & 4.26 \\
\hline 20. & $\begin{array}{l}\text { Students should use } \\
\text { much self- study mate- } \\
\text { rials to learn English. }\end{array}$ & 3 & 3.75 & 4 & 5.00 & 7 & 8.75 & - & - & 33 & 41.25 & 40 & 50.00 & 73 & 91.25 & 4.29 \\
\hline 21. & $\begin{array}{l}\text { Students have to evalu- } \\
\text { ate themselves to learn } \\
\text { better. }\end{array}$ & 4 & 5.00 & 1 & 1.25 & 5 & 6.25 & 5 & 6.25 & 47 & 58.75 & 23 & 28.75 & 70 & 87.50 & 4.05 \\
\hline 22. & $\begin{array}{l}\text { Students should mostly } \\
\text { study hat has been } \\
\text { mentioned under the } \\
\text { course because study- } \\
\text { ing } \mathrm{M} \text {. Ed. English } \\
\text { course is actually for } \\
\text { exam purpose. }\end{array}$ & 25 & 31.25 & 20 & 25.00 & 45 & 56.25 & 8 & 10.00 & 12 & $\begin{array}{lll}1 & 15.00\end{array}$ & 15 & 18.75 & 27 & 33.75 & 2.65 \\
\hline 23. & $\begin{array}{l}\text { Students should build } \\
\text { clear vision of their } \\
\text { learning before learn- } \\
\text { ing English. }\end{array}$ & 1 & 1.25 & 7 & 8.75 & 8 & 10.00 & 4 & 5.00 & 42 & 552.50 & 26 & 32.50 & 68 & 85.00 & 4.06 \\
\hline Grar & d Mean & & & & & & & & & & & & & & & 3.86 \\
\hline
\end{tabular}

Legend: No. = Item Serial Number, SD = Strongly Disagree, DA = Disagree, UD = Undecided, A = Agree, SA = Strongly Agree, $\mathrm{N}=$ Number of Responses, \% = Responses in Percentage

We see in table 8 that the vast majority, i.e. $92.50 \%$ agreed that the students have to be responsible for their own ways of practicing English. Similarly, a vast majority $91.25 \%$ agreed that students should use much self study materials to learn. Analyzing the responses to item 21 ; we can observe that $87.50 \%$ have agreed to the statement. Item 22 was to find out what they viewed regarding whether students mostly have to study has been mentioned under their course. The analysis shows that a majority, i.e. $56.25 \%$ disagreed it. The table above finally shows the students' responses on building their vision of learning before learning English. Majority or $85 \%$ agreed that they should build clear vision before learning. The grand mean for the category is 3.86 . 


\section{The role of teacher}

Table 9: Learners' perceptions of teachers' role

\begin{tabular}{|c|c|c|c|c|c|c|c|c|c|c|c|c|c|c|c|c|}
\hline \multirow{4}{*}{ No. } & \multirow{4}{*}{ Items } & \multicolumn{14}{|c|}{ Responses } & \multirow{4}{*}{$\sum^{\circ}$} \\
\hline & & \multicolumn{6}{|c|}{ Disagree } & \multirow{2}{*}{$\begin{array}{l}\text { Unde- } \\
\text { cided } \\
\text { UD } \\
\text { (3) }\end{array}$} & & \multicolumn{6}{|c|}{ Agree } & \\
\hline & & \multicolumn{2}{|c|}{ SD (1) } & $\begin{array}{l}\text { DA } \\
\text { (2) }\end{array}$ & \multicolumn{3}{|c|}{ Total } & & \multicolumn{2}{|c|}{$A(4)$} & \multicolumn{2}{|c|}{ SA (5) } & \multicolumn{2}{|c|}{ Total } & & \\
\hline & & $\mathbf{N}$ & $\%$ & $\mathbf{N}$ & $\%$ & $\mathbf{N}$ & $\%$ & $\mathbf{N}$ & $\%$ & $\mathbf{N}$ & $\%$ & $\mathbf{N}$ & $\%$ & $\mathrm{~N}$ & $\%$ & \\
\hline 24. & $\begin{array}{l}\text { A lot of learning can be done without } \\
\text { a teacher. }\end{array}$ & 4 & 5.00 & 9 & 11.25 & 13 & 16.25 & 4 & 5.00 & 39 & 48.75 & 24 & 30.00 & 63 & 78.75 & 3.88 \\
\hline 25. & $\begin{array}{l}\text { Teachers have to be responsible for } \\
\text { making students understand English. }\end{array}$ & 3 & 3.75 & 8 & 10.00 & 11 & 13.75 & 10 & 12.50 & 43 & 53.75 & 16 & 20.00 & 59 & 73.75 & 3.76 \\
\hline 26. & $\begin{array}{l}\text { Teachers should point out the students' } \\
\text { errors. }\end{array}$ & 7 & 8.75 & 11 & 13.75 & 18 & 22.50 & 6 & 7.50 & 36 & 45.00 & 20 & 25.00 & 56 & 70.00 & 3.64 \\
\hline 27. & $\begin{array}{l}\text { Teachers not only have to teach 'what' } \\
\text { but should also teach 'how' of English. }\end{array}$ & 1 & 1.25 & - & - & 1 & 1.25 & 4 & 5.00 & 31 & 38.75 & 44 & 55.00 & 75 & 93.75 & 4.46 \\
\hline 28. & $\begin{array}{l}\text { Teachers have to provide exam oriented } \\
\text { notes and materials. }\end{array}$ & 26 & 32.50 & 24 & 30.00 & 50 & 62.50 & 8 & 10.00 & 17 & 21.25 & 5 & 6.25 & 22 & 27.50 & 2.39 \\
\hline 29. & $\begin{array}{l}\text { The failure of the students is directly } \\
\text { related to the teachers' classroom em- } \\
\text { ployment. }\end{array}$ & 13 & 16.25 & 26 & 32.50 & 39 & 48.75 & 17 & 21.25 & 19 & 23.75 & 5 & 6.25 & 24 & 30.00 & 2.71 \\
\hline Gran & nd Mean & & & & & & & & & & & & & & & 3.47 \\
\hline
\end{tabular}

Table 9 shows that the great number of students, i.e. $78.75 \%$ agreed to the fact that a lot of learning can be done without a teacher. Among them, $16.25 \%$ disagreed the statement; while $5 \%$ of them could not decide on it. Regarding the teachers' responsibility to make students understand (item 25), majority of them i.e. $73.75 \%$ agreed on it. Item 26 was included in the tool to find out the role of teachers in error correction. It can be observed in the table that for $70 \%$, it is the teachers' responsibility to do so. Item 27 above was designed to investigate how students took that the teachers need to teach both the "what ' (content) and 'how' (process) of learning. A vast majority (93.75\%) agreed the statement. The table also shows that item 28 was agreed only by $27.50 \%$ of the students. Most of them, i.e. $62.50 \%$ thought that teachers should not provide exam oriented notes and materials. The $10 \%$ of the students remained undecided. The final item mentioned above (i.e. item 29) was designed to find out the connection of the students' failure with the teachers' classroom implementation. Around $48.75 \%$ did not agree it but $30 \%$ agreed it. The overall mean is 3.74 . 


\section{Teachers' perceptions of learner autonomy}

In order to investigate how teachers viewed autonomous learning, a structured interviewsheet with eight questions, was administrated. The responses of the teachers to eight different questions related to: significance of autonomous learning, autonomy-proficiency interlink, factors directing independent learning, performance differences, autonomous learning for examination, the teacher's role, assessing autonomy, and suggestions to the learners. Some of them are presented below:

\section{Factors directing independent learning}

The following factors have been found to be responsible factors for autonomous learning activities from teachers' perspectives 1) the temptation towards English/ intrinsic motivation; 2) expectation of better results in the final examinations; 3) due to the irregular classes it as a compulsion for them 4) learner awareness; 5) cultural factors; and 6) learners' other problems such as lack of time and access.

According to the teachers, the above factors were directing factors of autonomous learning. Most of the responses focused on the fact that it was mostly due to the expectation of better results in the final exams.

\section{The teachers' role}

Teachers were also asked of how they viewed their roles to foster autonomous learning of the learners. It was questioned whether they thought they should be authoritative, facilitator, co-worker or else. Some of them responded single role while some thought of more than one of such roles. Most of the replies included the role as a facilitator. The other roles which have been focused by minority and also chosen as the second one are co-worker, an aware person and also an authority person according to the situation.

\section{Suggestions to the learners}

The teachers were asked of their suggestion to both the less/non-autonomous (who particularly depended on teachers' lectures and classroom notes) and the autonomous learners (who were doing much on their own). The suggestions given by the teachers to the less/non-autonomous learners are: they should opt for the autonomous learning; they need to share and collaborate with the friends; they should come up with the new ideas and should try to find out the solutions to their problems themselves; they should consult books themselves; they should search the way so that they can be autonomous; they should keep a good contact for consultation with the teachers and others. The suggestions to autonomous learners are: they should keep on; they should come up with newer ideas and share with friends; they should be co-operative and should understand other friends, standing between and among them; should be more interactive and should have craze to learn more; should also go up with teachers; should help the poor, shy students to improve and make them autonomous.

\section{Findings}

The findings of the study show that more than $80 \%$ learners are found to be aware of the goals and the process of learning English. Around 71\% learners did a lot of self-efforts to improve and enhance their English. Learners, besides their classroom activities, perform many autonomous activities outside the class such as use of libraries, listening and watch audio-visual materials in English but are not found recording their voices. More than $66 \%$ learners assessed themselves though did not effort much to motivate self. Majority of the learners (i.e. $70 \%$ ) made use of reference materials, however, the modern technologies were used less. Only around $30 \%$ of the learners used computers and internet for learning English. More than 80\% learners perceived their own role as a great means to learning English. They took it that, for learning mostly a learner has to be responsible. They took learning much as a part of student efforts and also thought that they need to go beyond their learning of prescribed materials. They took the teachers' role as an important component of their learning. Though most of them agreed that a lot of learning can be done without teachers- the teachers should bring them out of the classroom learning. More than $74 \%$ teachers not only thought but also found as part of their experiences that autonomous learners were the 'good learners' in every case. These were also the situations from which they judged autonomy in learning. Regarding the 
teachers' role in such learning they take that it should be that of a facilitator. All the teachers felt that autonomous learning is the basis of better proficiency and performance, and it is quite beneficial.

\section{Conclusion}

The world of pedagogy is shifting rapidly from the authority to democracy since 1960s. The target of teaching/learning should be the learner autonomy. Many of the current theories of teaching/ learning also emphasize on the learner centered activities. The saying from Scharle and Szabö (2000, p.4): "you can bring the horse to the water, but you can not make him drink", can mark why autonomous learning is important. In language teaching, teachers can provide all the necessary circumstances and input; but learning can happen only if learners are willing to contribute, and only if they do. Their passive presence will not be enough, just as the horse would remain thirsty if he stood still by waiting patiently for his thirst to go away. Moreover, success in learning very much depends on learners having a responsible attitude. Now the time has come that 'brick houses' be turned into 'click houses', i.e. the traditional four walls of teaching should be replaced by the modern technologies of teaching. The lecture and note oriented classes have gone ragged and need to be replaced by the newer techniques. This implies the need for new humanistic trends in teaching learning. Learning learning is to be the demand of the academic roofs but not what something is without knowing what it is for and how. Hence, it is suggested that academic professionals have to make students the learners not the obedient parrots in their learning.

In the context like ours, now it has become a great responsibility for all the teachers to learn how we can teach our students the easier approaches to the learning. For this, we need to understand ourselves and develop our awareness in language teaching. This will lead us to the application of recent approaches in language learning. What we have to understand is to make our students do; we should initiate ourselves.

\section{The Author}

Khem Raj Joshi is a life member of NELTA. Currently, he teaches M.Ed. students at the Department of English Education, Tribhuvan University, Kirtipur, Kathmandu. His research interests are learner autonomy, learning strategies, learning styles and teacher professional development.

\section{References}

Allwright, R.L. (1990). Autonomy in language learning pedagogy. CRILE Working Paper 6. Centre for Research in Education: University of Lancaster.

Benson, P. (2007). Autonomy in language teaching and learning. State-of-the art article. Language teaching, 40 (1), 21-40.

Benson, P. and Voller, P. (1997). Autonomy and independence in language learning. London: Longman.

Boud, D. (Ed.). (1988). Developing student autonomy in learning. New York: Kogan Page.

Camilleri, G. (1999). Learner autonomy: The teachers' views. Germany: Council of Europe.

Candy, P. (1988). On the attainment of subject-matter autonomy. In D. Boud (Ed.). Developing student autonomy in learning ( $2^{\text {nd }}$ Edition). New York: Kogan, 59-76.

Cotterall, S. (1995). Readiness for autonomy: Investigating learner beliefs. System 23(2), 195-205.

Crabbe, D. (1993).Fostering autonomy from within the classroom: The teacher's responsibility. System, 21 (4), 443-52.

Dickinson, L. (1987). Self-Instruction in language learning. Cambridge: Cambridge University Press.

Esch, E. (1996). Self-access and the adult language learner. London: CILT

Freire, P. (1996). Pedagogy of the oppressed. London: Penguin.

Hedge, T. (2000). Teaching and learning in the language classroom. Oxford: OUP

Kenny, B. (1993). For more autonomy. System, 21(4), 431-42.

Kupfer, J. A. (1990). Autonomy and social interaction. Albany: state university of New Pork press.

Lamb, T. and Reinders, H. (2008). Learner and teacher autonomy: Concepts, realities and responses. Netherlands: John Benjamin Publishing 
Little, D. (1991). Learner autonomy: Definitions, issues and problems. Dublin: Authentik.

Pakkanli Egel, I. (2009). Learner autonomy in language classroom: From teacher dependency to learner dependency. Retrieved November 2, 2009 from www. Sciencedirect.com.

Pennycook, A. (1997) Cultural alternatives and autonomy. In Benson, P \& Voller, P. (Eds.) Autonomy \& independence in language learning. (pp. 35-53). London and New York: Longman.
Scharle, A. and Szabö, A. (2000). Learner autonomy. Cambridge: CUP.

Little et al. (2007). Preparing teachers to use the European Language Portfolio - arguments, materials and resources. Council of Europe: Council of Europe Publishing

Young, R. (1986). Personal autonomy: Beyond negative and positive liberty. London: Croom Helm. 


\section{Appendix- I}

\section{Learner Autonomy Survey Questionnaire (for the students)}

\section{Part I: Personal Profile}

Please give your personal information as asked.

Name:

Age:

Gender:

Address:

Study Year:

No. of Years Involved in Studying English:

Part II: Autonomous Learning Activity Scale

$$
\begin{array}{ll}
\mathrm{A}=\text { Never } & \mathrm{B}=\text { Rarely } \\
\mathrm{C}=\text { Sometimes } & \mathrm{D}=\text { Often } \\
\mathrm{E}=\text { Always } &
\end{array}
$$

\begin{tabular}{|c|c|c|c|c|c|c|}
\hline S.N. & Autonomous Learning Activities and Plans & $\mathbf{A}$ & B & $\mathbf{C}$ & $\mathbf{D}$ & $\mathbf{E}$ \\
\hline 1. & I think I have the ability to learn English well. & & & & & \\
\hline 2. & I make decisions and set goals of my learning. & & & & & \\
\hline 3. & I make good use of my free time in studying English. & & & & & \\
\hline 4. & I preview before the class (i.e. see summary, lessons etc.). & & & & & \\
\hline 5. & $\begin{array}{l}\text { In the class, I try to use every opportunity to take part in the } \\
\text { activities where and when I can speak in English. }\end{array}$ & & & & & \\
\hline 6. & I speak confidently in front of the people. & & & & & \\
\hline 7. & I make notes and summaries of my lessons. & & & & & \\
\hline 8. & I talk to the teachers and friends outside the class in English. & & & & & \\
\hline 9. & $\begin{array}{l}\text { I practice English outside the class also such as: record my own voice; } \\
\text { speak to other people in English. }\end{array}$ & & & & & \\
\hline 10. & I use library to improve my English. & & & & & \\
\hline 11. & $\begin{array}{l}\text { I use audio-visual materials to develop my speech such as: listen to } \\
\text { BBC, watch English movies, read English newspapers etc. }\end{array}$ & & & & & \\
\hline 12. & $\begin{array}{l}\text { I attend different seminars, training courses, conferences (e.g. } \\
\text { NELTA) to improve my English. }\end{array}$ & & & & & \\
\hline 13. & I take risk in learning the English language. & & & & & \\
\hline 14. & $\begin{array}{l}\text { I note my strengths and weaknesses in learning English and improve } \\
\text { them. }\end{array}$ & & & & & \\
\hline 15. & I revise lessons and seek the reference books. & & & & & \\
\hline 16. & $\begin{array}{l}\text { Besides the contents prescribed in the course, I read extra materials } \\
\text { in advance. }\end{array}$ & & & & & \\
\hline
\end{tabular}

This scale is meant to know about your own independent learning activities and plans that you adopt for learning English language. Please give a tick $(\sqrt{ })$ to the answers according to your true cases. 


\begin{tabular}{|l|l|l|l|l|l|l|}
\hline 17. & $\begin{array}{l}\text { When I make progress in learning, I reward myself such as: buy new } \\
\text { things, celebrate parties etc. }\end{array}$ & & & & \\
\hline 18. & I use internet and computers to study and improve English. & & & & \\
\hline
\end{tabular}

\section{Part III: Evaluation-Sheet for Perception of the Roles}

This section requires your true perceptions about the role of a teacher and that you think of yourself in learning English. Please circle the answer that you think is the best.

$1=$ Strongly Disagree $\quad 2=$ Disagree
$3=$ Undecided
$5=$ Strongly Agree

19. Students have to be responsible for finding their own ways of practicing English.

\begin{tabular}{|l|lllll|l|}
\hline strongly disagree & 1 & 2 & 3 & 4 & 5 & strongly agree \\
\hline
\end{tabular}

20. Students should use much self- study materials to learn English.

\begin{tabular}{|l|lllll|l|}
\hline strongly disagree & 1 & 2 & 3 & 4 & 5 & strongly agree \\
\hline
\end{tabular}

21. Students have to evaluate themselves to learn better.

\begin{tabular}{|l|lllll|l|}
\hline strongly disagree & 1 & 2 & 3 & 4 & 5 & strongly agree \\
\hline
\end{tabular}

22. Students should mostly study what has been mentioned under the course because studying M. Ed. English course is actually for exam purpose.

\begin{tabular}{|l|lllll|l|}
\hline strongly disagree & 1 & 2 & 3 & 4 & 5 & strongly agree \\
\hline
\end{tabular}

23. Students should build clear vision of their learning before learning English.

\begin{tabular}{|l|lllll|l|}
\hline strongly disagree & 1 & 2 & 3 & 4 & 5 & strongly agree \\
\hline
\end{tabular}

24. A lot of learning can be done without a teacher.

\begin{tabular}{|l|lllll|l|}
\hline strongly disagree & 1 & 2 & 3 & 4 & 5 & strongly agree \\
\hline
\end{tabular}

25. Teachers have to be responsible for making students understand English.

\begin{tabular}{|l|lllll|l|}
\hline strongly disagree & 1 & 2 & 3 & 4 & 5 & strongly agree \\
\hline
\end{tabular}

26. Teachers should point out the students' errors.

\begin{tabular}{|l|lllll|l|}
\hline strongly disagree & 1 & 2 & 3 & 4 & 5 & strongly agree \\
\hline
\end{tabular}

27. Teachers not only have to teach 'what' but should also teach 'how' of English.

\begin{tabular}{|l|lllll|l|}
\hline strongly disagree & 1 & 2 & 3 & 4 & 5 & strongly agree \\
\hline
\end{tabular}

28. Teachers have to provide exam oriented notes and materials.

\begin{tabular}{|l|lllll|l|}
\hline strongly disagree & 1 & 2 & 3 & 4 & 5 & strongly agree \\
\hline
\end{tabular}

29. The failure of the students is directly related to the teachers' classroom employment.

\begin{tabular}{|l|lllll|l|}
\hline strongly disagree & 1 & 2 & 3 & 4 & 5 & strongly agree \\
\hline
\end{tabular}

30. Teachers need to use their authority in teaching/learning if needed.

\begin{tabular}{|l|llllll|l|}
\hline strongly disagree & 1 & 2 & 3 & 4 & 5 & strongly agree \\
\hline
\end{tabular}

31. The student-teacher relationship is that of raw-material and maker.

\begin{tabular}{|l|lllll|l|}
\hline strongly disagree & 1 & 2 & 3 & 4 & 5 & strongly agree \\
\hline
\end{tabular}




\section{Appendix- II \\ Interview Question-Sheet (Only for the Teachers)}

1. How do you take autonomous learning in learning English?

2. Do you think that the students who are more autonomous in learning have higher proficiency?

3. What do you think are the factors/ things that direct such independent learning or self study?

4. What differences do you find between the autonomous and non- autonomous learners regarding their performance?

5. Do you think that this sort of activities have any connection with exam results in the department?

6. What do you think that a teacher's role in such learning should be?

7. How do you assess whether the learners are autonomous or not?

8. What would you like to suggest those learners of English who much depend upon the teachers and the classroom lectures or notes? And what about the autonomous learners? 